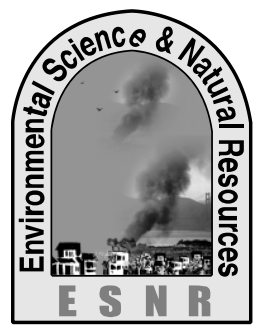

\title{
Determination of Drinking Water Quality: A Case Study on Saline Prone South-West Coastal Belt of Bangladesh
}

\section{T. K. Das*, M. Choudhury and M. Sultana}

Department of Environmental Science \& Technology, Jessore Science \& Technology University, Jessore-7408, Bangladesh.

*Corresponding author: tkdas@just.edu.bd

\begin{abstract}
This research integrates quantitative data of underground and sub-surface sources of drinking water from two coastal union Gabura and Munshiganj of Shyamnagur upazila of Satkhira district. Four drinking water sources have been selected and sampled during dry season when the salinity rate is generally high. A total of 22 water samples have been collected of which 6 from protected pond, 6 from tube well, 6 from rainwater and 4 from pond sand filter (PSF). The average $\mathrm{pH}$ of tube well water, protected pond water, pond sand filter water and rain water were $6.59( \pm .05), 6.46( \pm 1.03), 6.60( \pm .52), 5.95( \pm .87)$, respectively. The average EC $\left(\mu \mathrm{s} \mathrm{cm}^{-1}\right)$ range of tube well water, protected pond water, pond sand filter water and rain water were $2059.16( \pm 49.43), 1756( \pm 14), 769$ $( \pm 94.27), 64.33( \pm 59.91)$ while the TDS $(\mathrm{ppm})$ range were $1319.97( \pm 31.69), 1125.64( \pm 913.46), 492.94( \pm 60.43)$ and 15.38 $( \pm 118.59)$ respectively. The maximum concentration of salinity was found in tube well water which was $1.37( \pm 53)$ ppt. Most of the protected ponds were highly contaminated with sulphate and it ranges from 84.64 to $218.25 \mathrm{ppm}$. The average number of fecal Coliform in protected ponds were $1650100 \mathrm{~m} \mathrm{l}^{-1}$ of water while in PSF source pond $2350100 \mathrm{ml}^{-1}$ and collection point $1.5100 \mathrm{ml}^{-1}$.
\end{abstract}

Key words: Climate change, Ground water, Rainwater, Surface water and Water quality

\section{Introduction}

Water is precious natural resource for sustaining life and environment (Mishra, 2003). Man requires about 1.89 liters water daily for drinking but unsafe drinking water is the growing concern among the world communities (Park, 2005). The southernmost part of Bangladesh is bordered by about $710 \mathrm{~km}$ long coastal belt (Abedin, 2010). In the coastal belt of Bangladesh, excessive salinity in the water is making the lives of people miserable (Ghosh et al., 2000). Climate change induced sea level rise and extreme weather events poses a grave threat of inundation of coastal region with saline water and consequent salinity intrusion in surface and ground water create acute drinking water problem (Rana, 2011). Therefore different alternative sources of safe drinking are being explored e.g. RWHS, PSF, DTW (Ahmed, 1993). Groundwater is one of the major natural resource of the country for safe drinking water supply. But the presence of arsenic in shallow aquifer has completely changed this situation. About $50 \%$ of the ground water using area is unsuitable for use by hand tube wells due to arsenic contamination (Rahman et al., 2001). The salinity in the coastal area of Bangladesh has also imposed a serious threat to the underground sources of safe drinking water (Uttran, 2003). Surface water is generally free from arsenic in Bangladesh (Ahmed et al., 2005). During dry season the main source of drinking water were ponds which were specially conserved for drinking purposes (Ahmed, 2002). The main problems of ponds are excessive algal growth in dry season and fecal coli form range from 500 to several thousand per $100 \mathrm{ml}$ (Rahman et al., 2001). The PSF is an alternative technique to purify pond water (Ahmed and Rahaman, 2000). The Department of Public Health Engineering, Bangladesh and United Nation International Children's Emergency Fund jointly stated that, it is capable of producing potable water from pond water by removing harmful organisms, impurities and Turbidity (DPHE and UNICEF, 1989). In coastal zone of Bangladesh over $60 \%$ of these PSFs are out of order and the rural people are very reluctant to use PSFs due to over operation and maintenance problem (Ahmed, 2002). Rain water harvesting system provides salinity and arsenic free water (Hussain and Ziauddin, 1989). Rain water harvesting was in practice in varying degrees throughout Bangladesh and most of them use large earthenware pots (Motka) for storage. It is necessary to mention that an average of $2500 \mathrm{~mm}$ rainfall occurs annually in our country. So, the heavy seasonal rainfall makes rainwater harvesting a viable option of drinking water (Rahman, 2001). In most part of the country, people normally can have access to rainwater for about 6-8 months (Ahmed, 1999). Due to contaminated water coastal people suffer from different types of diseases, mostly water bone disease. So, this research was targeted to determine the water quality of surface and ground water sources. This research will help policy makers to find out suitable drinking water source for the coastal people.

\section{Materials and Methods}

Twenty two water samples were collected from Gabura and Munshiganj union of Shyamnagur upazila of Satkhira district which is in the marginal line of coastal zone. The drinking water sources in the two unions are not so available like others. Six samples were collected from each of protected pond, tube well, rain water and four sample from PSF. The water sample were collected in December 2012. The water samples were collected in one liter plastic pot which was previously washed and rinsed three times with sample water. Only for fecal coli form the water sample were collected in $250 \mathrm{ml}$ pot which was preserved in ice box. The $\mathrm{P}^{\mathrm{H}}$ was measured at the sampling site by Microprocessor $\mathrm{pH}$ meter model no. HANNA instrument, $\mathrm{pH} 211$. EC, Salinity and TDS were also measured at the sampling site by Conductivity meter model-HI 8033. The measurement of sodium and potassium were done by flame photometric method model- Flame photometer - PEP7. 
Total Hardness, Calcium, Magnesium and Bi-carbonate were analyzed by titration colorimetric method and chloride by titration

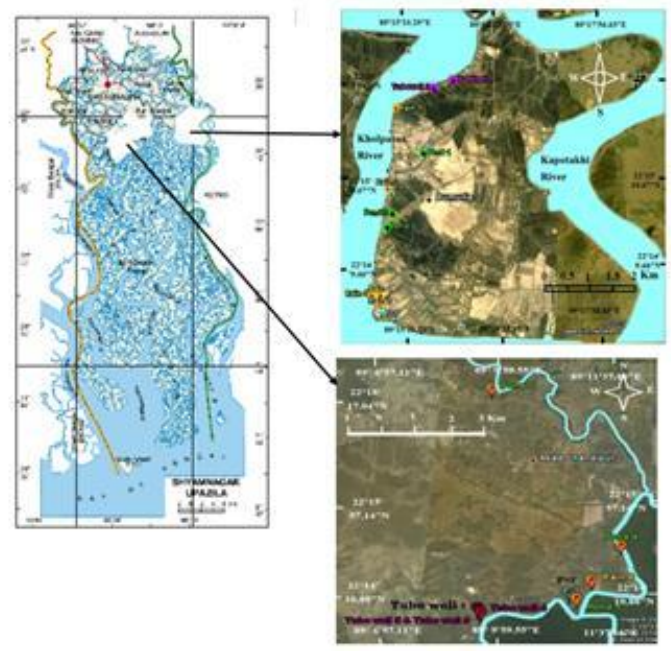

Fig. 1. Map of Gabura and Munshigonj Union of Shyamnagur Upazila, Bangladesh. (Source: Banglapedia and google earth.)

Argenometric method. Nitrate, Phosphate and Sulphate were measured by Turbidimetric method with Spectrophotometer model- Thermospectronic, UVvisible spectrophotometers, helios 949923045811. Fecal coliform was count by pore plate culture method (Ramesh and Anbu, 1996). Data were analyzed by Excel 2007 software. SPSS 20 software was used for statistical analysis, such as Pearson Correlation. Pearson Correlation establish relationship between parameters of water quality i.e. whether a parameter increase or decrease with the increase and decrease of other parameters.

\section{Results and Discussion}

\section{Quality assessment}

Descriptive statistics including minimum, maximum and mean concentration of water quality variables for all water sources are presented in Table 1 . The salinity in two rain water samples were below detection limit, which was considered as $0 \mathrm{ppm}$ for further statistical analysis.

\section{pH, Salinity, EC and TDS}

The observed $\mathrm{pH}$ value of protected pond water ranges from 4.48-7.28 (Table 1). The surface water of the coastal area is sulphate-chloride dominated (Rahman et al., 2000). The black soil of coastal area contains sodium sulphate. Sulphate in surface water mainly arises from runoff through black soil and acid rain. The average $\mathrm{pH}$ of tube wells water $6.59( \pm 0.05)$ (Table 1$)$. EC and TDS in Tube well water sample show a negative correlation with $\mathrm{pH}$ where $\mathrm{r}=-.89$ and -.89 respectively (Table 2). The $\mathrm{pH}$ of ground water was varied from 7.1 to 7.25 (Sikder et al., 2009) which is slightly higher than obtained value. The $\mathrm{pH}$ of Pond Sand Filter were mainly influenced by connected pond water and its average value was $6.46( \pm 1.03)$.

Generally, the $\mathrm{pH}$ of rainwater ranges from 4.5 to 6.5 but increases slightly after falling on the roof and during storage in tanks (Gobel et al., 2007; Meera and Ahammed, 2006). However the average investigated value were $5.95( \pm .87)$ (Table 1$)$ but one of our results indicates higher $\mathrm{pH}$ value, in the range of 6.54 and 8.25 those results were found in Greece (Melidis et al., 2007). The similar results also found in another coastal district Barguna, which was 6.23 (Saha et al., 2006). The $\mathrm{p}^{\mathrm{H}}$ of harvested rainwater show a positive correlation with salinity, EC, TDS, $\mathrm{Na}, \mathrm{K}, \mathrm{Ca}, \mathrm{PO}_{4}$, $\mathrm{NO}_{3}, \mathrm{Cl}$ and $\mathrm{HCO}_{3}$ and all of the cases this correlation is highly significant (Table 5). According to World Health Organization (WHO) the $\mathrm{p}^{\mathrm{H}}$ of drinking water range from 6.5-9.2 and Bangladesh Standard and Testing Institute (BSTI) 6.4-7.4.

Pure water has a very low electrical conductance, less than tenth of a micro Siemens at $25^{\circ} \mathrm{C}$ (Sikder et al., 2009). The electrical conductivity of Tube wells water range from $1975 \mu \mathrm{s} \mathrm{cm}^{-1}$ to $2110 \mu \mathrm{s} \mathrm{cm}^{-1}$ with a mean of $2059.16( \pm 49.43) \mu \mathrm{s} \mathrm{cm}^{-1}$ (Table 1$)$, where a highly significant correlation was found between EC and TDS (Table 2). The predicted EC value of harvested rainwater ranges from $24 \mu \mathrm{s} \mathrm{cm}^{-1}$ to $185 \mu \mathrm{s} \mathrm{cm}^{-1}$ with a mean of $64.33( \pm 59.91) \mu \mathrm{s} \mathrm{cm}^{-1}$, which was lower than those found in Ghana (2.03 to $102 \mu \mathrm{s} \mathrm{cm}^{-1}$ ) (Cobbina et al., 2013). From the Pearson correlation it was found that EC has a significant positive correlation with Salinity, TDS, $\mathrm{Na}, \mathrm{K}, \mathrm{Ca}, \mathrm{Cl}$ and $\mathrm{HCO}_{3}$ (Table 5). The electrical conductivity of four protected pond range between 772 to $1235 \mu \mathrm{sm}^{-1}$ but two have exceptional results 2150 and $4480 \mu \mathrm{s} \mathrm{cm}^{-1}$ respectively. Those two protected pond are constructed in newly developed sandy land along the river.

The EC value increased with increasing the concentration of dissolve matter (Deletic, 1998). In case of pond sand filters the mean conductivity were 769 ( \pm 94.27) $\mu \mathrm{s} \mathrm{cm}^{-1}$ (Table 1), which have a significant positive correlation with TDS, $\mathrm{Na}$ and $\mathrm{NO}_{3}$ and negative correlation with $\mathrm{SO}_{4}$ (Table 4). Richards (1968), categorized water salinity in three sections on the basis of electrical conductivity. Category one $\mathrm{EC}<250 \mu \mathrm{s} \mathrm{cm}^{-1}$ represents low salinity, category two $\mathrm{EC}=251-750 \mu \mathrm{sm}^{-1}$ represents medium salinity and category three EC>751 $\mathrm{s} \mathrm{cm}^{-1}$ represents high salinity. From the result it was found that except harvested rainwater, all the water sources are within high salinity range (Table 1). The similar results was found in another coastal district Bagherhat, where surface (pond) water contain 1.28 to $2.25 \mathrm{ppt}$ and ground (tube-well) water contain 2.05 to $2.67 \mathrm{ppt}$ of salt in dry season (Haque et al., 2010). Salinity has a positive correlation with EC, TDS, $\mathrm{Na}, \mathrm{K}, \mathrm{Ca}, \mathrm{Cl}$ and $\mathrm{HCO}_{3}$ but for all the water sources negative correlation was found with $\mathrm{SO}_{4}$. 
Table 1. Physico-chemical properties of collected water samples Tube well water

Pond Sand Filter water

Protected Pond water Rain water

\begin{tabular}{|c|c|c|c|c|c|c|c|c|c|c|c|c|c|}
\hline Parameter & Units & Min & Max & Mean \pm S. D. & Min & Max & Mean \pm S. D. & Min & Max & Mean \pm S. D. & Min & Max & Mean \pm S.D. \\
\hline $\mathrm{pH}$ & & 6.53 & 6.66 & $6.5950 \pm .05$ & 6.25 & 7.38 & $6.60 \pm .52$ & 4.48 & 7.28 & $6.46 \pm 1.03$ & 5.48 & 7.73 & $5.955 \pm .87$ \\
\hline Salinity & ppt & 0.99 & 2.1 & $1.375 \pm .53$ & 0.33 & 0.43 & $.377 \pm .04$ & 0.38 & 2.23 & $.881 \pm .711$ & 0 & 0.08 & $.0183 \pm .03$ \\
\hline $\mathrm{EC}$ & $\mu \mathrm{scm}^{-1}$ & 1975 & 2110 & $2059.166 \pm 49.43$ & 687 & 872 & $769 \pm 94.27$ & 772 & 4480 & $1756 \pm 1425$ & 24 & 185 & $64.33 \pm 59.91$ \\
\hline TDS & $\mathrm{ppm}$ & 1266.03 & 1352.56 & $1319.97 \pm 31.69$ & 440.38 & 558.97 & $492.94 \pm 60.43$ & 494.87 & 2871.79 & $1125.64 \pm 913.46$ & 15.38 & 118.59 & $41.23 \pm 38.40$ \\
\hline $\mathrm{Na}^{+}$ & ppm & 126 & 587.76 & $311.36 \pm 207.73$ & 6.84 & 56.76 & $30.24 \pm 21.84$ & 13.08 & 662.64 & $262.78 \pm 232.48$ & 0.58 & 6.89 & $2.325 \pm 2.39$ \\
\hline $\mathrm{K}^{+}$ & $\mathrm{ppm}$ & 1.01 & 1.42 & $1.195 \pm .13$ & 10.2 & 11.74 & $11.09 \pm .77$ & 8.42 & 89.24 & $17.69 \pm 15.56$ & 0.6 & 3.89 & $1.42 \pm 1.26$ \\
\hline $\mathrm{Ca}^{+2}$ & $\mathrm{ppm}$ & 132.25 & 248.48 & $178.34 \pm 51.8$ & 24.06 & 48.09 & $38.07 \pm 12.01$ & 36.07 & 92.17 & $60.11 \pm 25.72$ & 1 & 7.01 & $4.338 \pm 2.34$ \\
\hline $\mathrm{Mg}^{2+}$ & ppm & 43.74 & 89.93 & $60.76 \pm 17.32$ & 17.01 & 26.73 & $22.47 \pm 4.15$ & 17.01 & 123.95 & $53.46 \pm 38.64$ & 0.6 & 3.03 & $1.615 \pm .99$ \\
\hline $\mathrm{SO}_{4}^{-2}$ & $\mathrm{ppm}$ & 0.91 & 9.57 & $5.88 \pm 3.04$ & 84.64 & 218.25 & $150.90 \pm 57.81$ & 51.35 & 498.22 & $190.30 \pm 161.38$ & 5.13 & 14.69 & $11.02 \pm 3.65$ \\
\hline $\mathrm{PO}_{4}^{-3}$ & ppm & 0.03 & 0.2 & $.106 \pm .0628$ & 0.03 & 0.07 & $.045 \pm .01$ & 0.01 & 0.07 & $.0383 \pm .02$ & 0.01 & 0.21 & $.083 \pm .072$ \\
\hline $\mathrm{NO}_{3}^{-2}$ & $\mathrm{ppm}$ & 1.22 & 1.64 & $1.398 \pm .160$ & 0.82 & 2.27 & $1.44 \pm .718$ & 1.21 & 2.04 & $1.675 \pm .31$ & 1.13 & 3.32 & $2.24 \pm .87$ \\
\hline $\mathrm{Cl}^{-}$ & ppm & 673.55 & 1737.05 & $1045.77 \pm 523.29$ & 70.9 & 230.42 & $155.09 \pm 87.28$ & 212.7 & 2038.37 & $667.63 \pm 693.37$ & 3.54 & 14.18 & $7.68 \pm 3.48$ \\
\hline
\end{tabular}

Distribution of Total Dissolve Solid among alternative water options is shown in Table 1. The PSF water (mean $492.94 \pm 60.43 \mathrm{ppm}$ ) and rain water (mean $41.23 \pm 38.4 \mathrm{ppm}$ ) were found within the acceptable limit of drinking water quality standards. The total dissolved solids (TDS) in rainwater, originating from particulate matter suspended in the atmosphere usually range from $2 \mathrm{Ppm}$ to $20 \mathrm{ppm}$ (Hari and Krishna, 2005). This result is slightly lower than experimented value. In harvested rain water sample TDS show a significant correlation with $\mathrm{Na}, \mathrm{K}, \mathrm{Ca}, \mathrm{Cl}$ and $\mathrm{HCO}_{3}$. The TDS concentration in tube well water (mean $1319.97 \pm 31.69 \mathrm{ppm}$ ) and protected pond water (mean $1125.64 \pm 913.46 \mathrm{ppm}$ ) were slightly higher than acceptable limit of drinking water quality.

Water containing more than 500 ppm of TDS is not considered desirable for drinking water supplies, though more highly mineralized water may be used where better quality water is not available (Jain, 2002). But of unavoidable case $1500 \mathrm{ppm}$ of TDS is also allowed (Gopalkrushna, 2011). The TDS concentration of protected pond water were higher than other sources, where a significant positive correlation was found with $\mathrm{Na}, \mathrm{K}, \mathrm{Mg}$ and $\mathrm{Cl}$.

\section{Ca, Mg, Na, K and Total Hardness}

The mean concentration of calcium in protected pond water, tube well water and pond sand filter water were $60.11( \pm 25.72) \mathrm{ppm}, 178.34( \pm 51.8) \mathrm{pm}$ and $38.07( \pm 12.01)$ ppm respectively (Table 1). The similar results was found in another coastal districts Bagerhat, where the calcium concentration in surface water range from 82.10-118.20 ppm and underground water 46.5-122.15 ppm (Haque et al., 2010). 

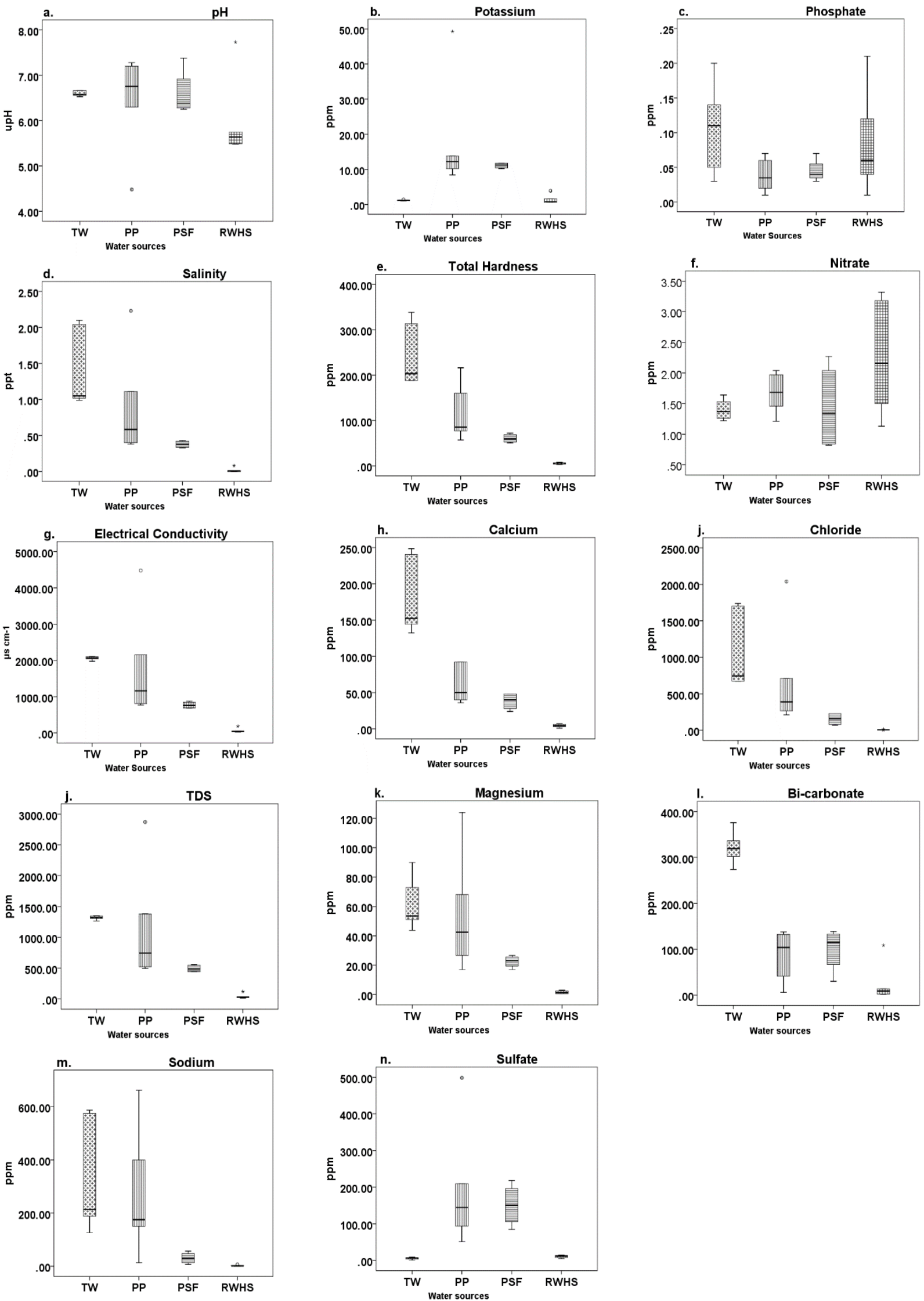

Fig. 1. Box plot diagram (a-n) of water quality parameter for each source. Abbreviations: $T W=T u b e ~ W e l l ; ~ P P=$ Protected Pond; PSF= Pond Sand Filter; RWHS= Rain Water Harvesting System

Increased amount of $\mathrm{Ca}_{2}^{+}$and $\mathrm{Mg}_{2}^{+}$in rain water may be attributed to the influence of crustal aerosols coupled with anthropogenic emissions (Kulshrestha et al., 1995). In rain water sample calcium show significant 
positive correlation with $\mathrm{pH}$, salinity, EC and potassium. The total hardness in protected pond water (mean $113.57 \pm 61.32 \mathrm{ppm}$ ), tube well water (mean $239.10 \pm 68.03 \mathrm{ppm}$ ), pond sand filter water (mean $60.55 \pm 9.99 \mathrm{ppm}$ ) and rain water (mean $5.85 \pm 1.75$ ppm) (Fig. 1, e) were much lower than BSTI drinking water quality standards which is 500 ppm (Ahmed, 2010). The detected quantities of sodium in PSF water $(30.24 \pm 21.84 \mathrm{ppm})$ and rain water $(2.32 \pm 2.39 \mathrm{ppm})$ were within the drinking water quality standards. According to WHO drinking water quality standard the maximum concentration of sodium is $200 \mathrm{ppm}$ (WHO, 2004). The sodium concentration in tube well water $(311.36 \pm 207.73 \mathrm{ppm})$ and protected pond water $(262.78 \pm 232.48 \mathrm{ppm})$ were higher than WHO drinking water quality standards (Fig. 1, m). In all the water samples sodium shows significant positive correlation with salinity. Sodium is commonly taken as the best as the reference element for marine source (Kulshrestha et al., 2003). The potassium concentration in protected pond water (17.69 $\pm 15.56 \mathrm{ppm}$ ) (Fig. 1, b) were higher than BSTI drinking water quality standards which is 12 ppm (BBS, 2011). The potassium ion in protected pond water sample show significant positive correlation with salinity, EC and TDS. The detected quantities of

\section{$\mathrm{Cl}, \mathrm{HCO}_{3}, \mathrm{PO}_{4}, \mathrm{SO}_{4}$ and $\mathrm{NO}_{3}$}

The chlorine concentration in tube well water samples $(1045.77 \pm 523.29 \mathrm{ppm}$ ) (Fig. 1, i) were two times higher than BSTI drinking water quality standards which is $600 \mathrm{ppm}$ (Ahmed, 2010). Chloride has significant positive correlation with salinity, sodium and calcium but negative correlation with phosphate. The detected quantities of chlorine in protected pond water (667.63 $\pm 693.37 \mathrm{ppm})$, PSF water $(155.09 \pm 87.28$ $\mathrm{ppm})$ and rain water $(7.68 \pm 3.48 \mathrm{ppm})$ were within the limit of BSTI drinking water quality standards (Fig. 1, i). The chlorine concentration in drinking water for Bangladesh proposed by Asian Development Bank was 150-600 ppm (ADB, 1994). The average concentration of bi-carbonate in protected pond water, tube well water, PSF water and rain water were $87.53( \pm 54.45)$ ppm, 321.05( \pm 34.268$) \mathrm{ppm}, 99.69( \pm 48.51) \mathrm{ppm}$ and $24.29( \pm 41.69)$ ppm respectively (Fig. 1, 1). A study in Ghana found $9.41( \pm 7.6) \mathrm{ppm}$ of bi-carbonates in rainwater, which is slightly lower than current study (Gobel et al., 2007). Distribution of phosphate among water sources is shown in Fig. 1, c. All the water sources, protected pond water $(0.03 \pm .02 \mathrm{ppm})$, tube well water $(0.11 \pm .06 \mathrm{ppm})$, PSF water $(0.04 \pm .01 \mathrm{ppm})$ and rain water $(0.08 \pm .07 \mathrm{ppm})$ contain small amount of phosphate compared to ADB proposed drinking water quality standards. The potassium exhibits negative correlation with sulfate. The concentration of phosphate in harvested rainwater was similar to those reported at some other locations of India (Das et al., 2005; Pandey and Pandey, 2009).The maximum permissible limit of phosphate in drinking water $6 \mathrm{ppm}$, ADB proposed water quality standard for Bangladesh (ADB, 1994). The maximum permissible limit of phosphate for irrigation water 20 ppm (Ayer and Westcot, 1985). potassium in other drinking water sources were within the acceptable limit of Bangladesh and WHO drinking water quality standards. The detected quantities of sodium in PSF water $(30.24 \pm 21.84 \mathrm{ppm})$ and rain water $(2.32 \pm 2.39 \mathrm{ppm})$ were within the drinking water quality standards. According to world health organization drinking water quality standard the maximum concentration of sodium is $200 \mathrm{ppm}$ (WHO, 2004). The sodium concentration in tube well water $(311.36 \pm 207.73 \mathrm{ppm})$ and protected pond water $(262.78 \pm 232.48 \mathrm{ppm})$ were higher than WHO drinking water quality standards (Fig. 1, m). In all the water samples sodium shows significant positive correlation with salinity. Sodium is commonly taken as the best as the reference element for marine source (Kulshrestha et al., 2003). The potassium concentration in protected pond water (17.69 $\pm 15.56 \mathrm{ppm})$ (Fig. 1, b) were higher than BSTI drinking water quality standards which is 12 ppm (BBS, 2011). The potassium ion in protected pond water sample show significant positive correlation with salinity, EC and TDS. The detected quantities of potassium in other drinking water sources were within the acceptable limit of Bangladesh and WHO drinking water quality standards.

The concentration of sulfate in tube well water $(5.88 \pm 3.04 \mathrm{ppm})$, PSF water $(150.90 \pm 57.81 \mathrm{ppm})$ and rain water $(11.02 \pm 3.65 \mathrm{ppm})$ are within the acceptable limit of BSTI and WHO drinking water quality standards (Fig. 1, n). A study in Ghana found 0.04 to $8.2 \mathrm{ppm}$ of Sulfate in rainwater which is similar to the present research (Cobbina et al., 2013). The sulfate ion shows negative correlation $\mathrm{pH}$. Sulfate concentration in protected pond water sample ranged from 51.35 to $498.22 \mathrm{ppm}$ with an average of $190.30( \pm 161.38) \mathrm{ppm}$ (Fig. 1, n). Sulfate occur in natural water at concentration up to $50 \mathrm{ppm}$. Concentration of $1000 \mathrm{ppm}$ can be found in water having contact with certain geological formations e. g. gypsum reserves, water from pyrite quarries (Kotaiah and Swamy, 1994). The mean concentration of nitrate in protected pond water, PSF water, tube well water and rain water were $1.67( \pm .31)$ ppm, $1.44( \pm .7)$ ppm, 1.39 ( \pm .16$)$ ppm and $2.24( \pm .87)$ ppm respectively which was negligible compared to WHO drinking water quality standards. Increased concentrations of nitrate in rain water could be due to emission of $\mathrm{N}$ oxides from the combustion of fossil fuel and biomass burning (Pandey et al., 1992; Ceron et al., 2008). The maximum permissible limit of nitrate in drinking water recommended by World Health Organization (WHO) is 45 ppm (Dara, 2002).

\section{Feical Coliform}

The number of feical coliforms in protected pond range from 700 to $2500 \mathrm{CFU} 100 \mathrm{ml}^{-1}$. PSF source pond have high bacterial contamination 2700 and 2000 CFU 100 $\mathrm{ml}^{-1}$ but at collection point it is 0 and $3 \mathrm{CFU} 100 \mathrm{ml}^{-1}$. PSF has high efficiency in bacteria removal from contaminated water. 


\section{Conclusion}

From the observation it can be concluded that the concentration of all water quality parameter in harvested rain water were within $\mathrm{WHO}$ and BSTI drinking water quality standards but other sources were not so suitable for drinking purpose. Most of the water quality parameter of protected pond, tube well and pond sand filter exceeds WHO and BSTI drinking water quality standards. As the coastal zone is situated in the transition zone of brackish water, the alternative drinking water sources is needed to ensure safe drinking water supply and reduce health risks of coastal people.

Table 2. Correlation matrix of major ions including $\mathrm{pH}$, EC, TDS for Tube well water

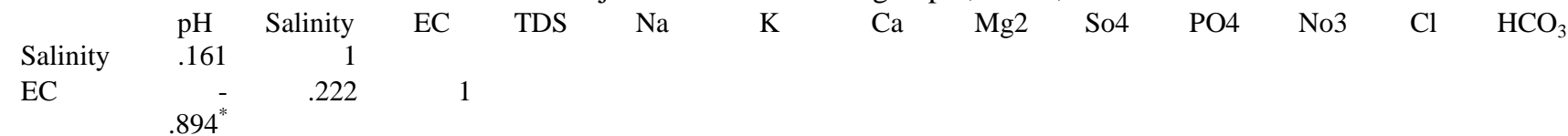

\begin{tabular}{|c|c|c|c|c|c|c|c|c|c|c|c|c|}
\hline TDS & $\begin{array}{c}.894^{*} \\
-894^{*}\end{array}$ & .222 & $1.00^{* *}$ & 1 & & & & & & & & \\
\hline $\mathrm{Na}$ & .223 & $.982^{* * *}$ & .139 & .139 & 1 & & & & & & & \\
\hline K & .739 & 649 & -.394 & -.394 & .621 & 1 & & & & & & \\
\hline $\mathrm{Ca}$ & .208 & $.988^{* *}$ & .148 & .148 & $.989^{* * *}$ & .614 & 1 & & & & & \\
\hline $\mathrm{Mg} 2$ & -.005 & $.936^{* * *}$ & .312 & .312 & $.878^{*}$ & .525 & $.916^{*}$ & 1 & & & & \\
\hline So 4 & -.389 & .301 & .572 & .572 & .166 & .006 & .274 & .396 & 1 & & & \\
\hline PO4 & -.171 & $-.820^{*}$ & -.130 & -.130 & $-.865^{*}$ & -.376 & $-.882^{*}$ & -.674 & -.338 & 1 & & \\
\hline No3 & -.518 & -.744 & .215 & .215 & -.687 & $-.904^{*}$ & -.700 & -.753 & -.057 & .340 & 1 & \\
\hline $\mathrm{Cl}$ & .154 & $.999^{* *}$ & .231 & .231 & $.979^{* *}$ & .640 & $.989^{* *}$ & $.933^{* *}$ & .335 & $-.837^{*}$ & -.729 & 1 \\
\hline $\mathrm{HCO} 3$ & .219 & -.636 & -.385 & -.385 & -.557 & -.134 & -.665 & -.781 & -.747 & .635 & .350 & -.658 \\
\hline
\end{tabular}

*. Correlation is significant at the 0.05 level (2-tailed). Cell Contains: Pearson correlation

**. Correlation is significant at the 0.01 level (2-tailed).

Table 3. Correlation matrix of major ions including pH, EC, TDS for Protected Pond water.

\begin{tabular}{|c|c|c|c|c|c|c|c|c|c|c|c|c|c|}
\hline Salinity & $\begin{array}{l}\mathrm{pH} \\
.662\end{array}$ & $\begin{array}{r}\text { Salinity } \\
1\end{array}$ & EC & TDS & $\mathrm{Na}$ & K & $\mathrm{Ca}$ & $\mathrm{Mg}$ & $\mathrm{SO}_{4}$ & $\mathrm{PO}_{4}$ & $\mathrm{NO}_{3}$ & $\mathrm{Cl}$ & $\mathrm{HCO}_{3}$ \\
\hline EC & .652 & $1.00^{* * *}$ & 1 & & & & & & & & & & \\
\hline TDS & .652 & $1.00^{\text {** }}$ & $1.000^{*}$ & 1 & & & & & & & & & \\
\hline $\mathrm{Na}$ & .729 & $.992^{* * *}$ & $.989^{* *}$ & $.989^{* *}$ & 1 & & & & & & & & \\
\hline K & .470 & $.943^{\text {** }}$ & $.950^{* *}$ & $.950^{* * *}$ & $.903^{*}$ & 1 & & & & & & & \\
\hline $\mathrm{Ca}$ & .688 & $.872^{*}$ & $.863^{*}$ & $.863^{*}$ & $.917^{*}$ & .713 & 1 & & & & & & \\
\hline $\mathrm{Mg}$ & .600 & $.989^{* * *}$ & $.987^{* *}$ & $.987^{* *}$ & $.977^{* * *}$ & $.917^{*}$ & $.879^{*}$ & 1 & & & & & \\
\hline $\mathrm{SO}_{4}$ & -.451 & .209 & .208 & .208 & .169 & .249 & .304 & .317 & 1 & & & & \\
\hline $\mathrm{PO}_{4}$ & .264 & .372 & .387 & .387 & .356 & .520 & .172 & .255 & -.341 & 1 & & & \\
\hline $\mathrm{NO}_{3}$ & -.414 & .041 & .053 & .053 & .013 & .260 & .071 & .010 & .467 & .480 & 1 & & \\
\hline $\mathrm{Cl}$ & .601 & $.987^{* * *}$ & $.991^{* *}$ & $.991^{* * *}$ & $.964^{* *}$ & $.976^{* *}$ & .793 & $.967^{* *}$ & .180 & .464 & .091 & 1 & \\
\hline $\mathrm{HCO}_{3}$ & .623 & .707 & .700 & .700 & 697 & .577 & .558 & .738 & .064 & -.228 & -.545 & .665 & 1 \\
\hline
\end{tabular}

**. Correlation is significant at the 0.01 level (2-tailed).

Cell Contains: Pearson correlation

*. Correlation is significant at the 0.05 level (2-tailed).

Table 4. Correlation matrix of major ions including $\mathrm{pH}, \mathrm{EC}$, TDS for Pond Sand Filter water.

\begin{tabular}{|c|c|c|c|c|c|c|c|c|c|c|c|c|}
\hline Salinity & $\begin{array}{l}\mathrm{pH} \\
.379\end{array}$ & $\begin{array}{r}\text { Salinity } \\
1\end{array}$ & EC & TDS & $\mathrm{Na}$ & K & $\mathrm{Ca}$ & $\mathrm{Mg}$ & $\mathrm{SO}_{4}$ & $\mathrm{PO}_{4}$ & $\mathrm{NO}_{3}$ & $\mathrm{Cl}$ \\
\hline $\mathrm{EC}$ & .358 & $.997^{* *}$ & 1 & & & & & & & & & \\
\hline TDS & .358 & $.997^{* * *}$ & $1.000^{* * *}$ & 1 & & & & & & & & \\
\hline $\mathrm{Na}$ & .235 & .930 & $.955^{*}$ & $.955^{*}$ & 1 & & & & & & & \\
\hline $\mathrm{K}$ & -.867 & -.010 & -.015 & -.015 & -.015 & 1 & & & & & & \\
\hline $\mathrm{Ca}$ & -.741 & -.902 & -.889 & -.889 & -.778 & .406 & 1 & & & & & \\
\hline $\mathrm{Mg}$ & .784 & .362 & .389 & .389 & .460 & -.878 & -.618 & 1 & & & & \\
\hline $\mathrm{SO}_{4}$ & -.185 & $-.961^{*}$ & -.948 & -.948 & -.849 & -.243 & .786 & -.089 & 1 & & & \\
\hline $\mathrm{PO}_{4}$ & -.266 & .790 & .798 & .798 & .797 & .578 & -.449 & -.169 & -.886 & 1 & & \\
\hline $\mathrm{NO}_{3}$ & .297 & $.993^{* *}$ & $.998^{* *}$ & $.998^{* *}$ & $.962^{*}$ & .041 & -.858 & .348 & $-.955^{*}$ & .834 & 1 & \\
\hline $\mathrm{Cl}$ & .548 & $.973^{*}$ & $.975^{*}$ & $.975^{*}$ & .923 & -.236 & $-.959^{*}$ & .565 & -.872 & .645 & $.960^{*}$ & 1 \\
\hline $\mathrm{HCO}_{3}$ & .434 & .737 & .777 & .777 & .890 & -.400 & -.726 & .788 & -.544 & .451 & .769 & .831 \\
\hline
\end{tabular}

**. Correlation is significant at the 0.01 level (2-tailed).

Cell Contains: Pearson correlation

*. Correlation is significant at the 0.05 level (2-tailed). 
Table 5. Correlation matrix of major ions including $\mathrm{pH}$, EC, TDS for Rainwater.

\begin{tabular}{|c|c|c|c|c|c|c|c|c|c|c|c|c|}
\hline Salinity & $\begin{array}{l}\mathrm{pH} \\
.995^{* *}\end{array}$ & $\begin{array}{r}\text { Salinity } \\
1\end{array}$ & $\mathrm{EC}$ & TDS & $\mathrm{Na}$ & K & $\mathrm{Ca}$ & $\mathrm{Mg}$ & $\mathrm{SO}_{4}$ & $\mathrm{PO}_{4}$ & $\mathrm{NO}_{3}$ & $\mathrm{Cl}$ \\
\hline $\mathrm{EC}$ & $.994^{* *}$ & $.997^{* *}$ & 1 & & & & & & & & & \\
\hline TDS & $.994^{* *}$ & $.997^{* *}$ & $1.000^{* *}$ & 1 & & & & & & & & \\
\hline $\mathrm{Na}$ & $.968^{* *}$ & $.961^{* * *}$ & $.954^{* *}$ & $.954^{* * *}$ & 1 & & & & & & & \\
\hline K & $.981^{* *}$ & $.976^{* *}$ & $.968^{* * *}$ & $.968^{* * *}$ & $.997^{* *}$ & 1 & & & & & & \\
\hline $\mathrm{Ca}$ & $.981^{* *}$ & $.976^{* *}$ & $.968^{* *}$ & $.968^{* *}$ & $.997^{* *}$ & $1.000^{* *}$ & 1 & & & & & \\
\hline $\mathrm{Mg}$ & -.183 & -.173 & -.177 & -.177 & -.301 & -.277 & -.277 & 1 & & & & \\
\hline $\mathrm{SO}_{4}$ & -.359 & -.336 & -.393 & -.393 & -.312 & -.303 & -.303 & .575 & 1 & & & \\
\hline $\mathrm{PO}_{4}$ & -.009 & .021 & -.025 & -.025 & .207 & .173 & .173 & -.346 & .448 & 1 & & \\
\hline $\mathrm{NO}_{3}$ & -.015 & .046 & -.014 & -.014 & .104 & .108 & .108 & -.158 & .602 & $.853^{*}$ & 1 & \\
\hline $\mathrm{Cl}$ & $.930^{* *}$ & $.941^{* *}$ & $.956^{* *}$ & $.956^{* *}$ & $.924^{* *}$ & $.924^{* *}$ & $.924^{* *}$ & -.333 & -.539 & .047 & -.019 & 1 \\
\hline $\mathrm{HCO}_{3}$ & $1.000^{* * *}$ & $.996^{* *}$ & $.995^{* * *}$ & $.995^{* * *}$ & $.962^{* *}$ & $.977^{* *}$ & $.977^{* *}$ & -.178 & -.366 & -.024 & -.018 & $.932^{* *}$ \\
\hline
\end{tabular}

*. Correlation is significant at the 0.05 level (2-tailed).

\section{References}

Abedin, M. Z. 2010. Global Warming, Climate Change and Impact on Agriculture in Bangladesh. $4^{\text {th }}$ National Convention of Krishibid Institute, Bangladesh.

ADB (Asian Development Bank). 1994. Training Manual for Environmental Monitoring. Engineering Science, INC., USA, pp 2-16.

Ahmed, M. F. 2002. Coastal Water Supply in Bangladesh Recharging the Undercharged: Challenge for the $21^{\text {st }}$ Century, $22^{\text {nd }}$ WEDC Conference, New Delhi, India.

Ahmed, M. F. 1999. Rainwater Harvesting Potentials in Bangladesh, Proceedings of $25^{\text {th }}$ WEDC Conference on Integrated Development for Water Supply and Sanitation, Addis Ababa, Ethiopia.

Ahmed, M. F. 1993. Prospects for rain water catchment in Bangladesh and its utilization. Proceeding of $6^{\text {th }}$ international conference on rainwater catchment system, Nairobi, Kenia.

Ahmed, M. J.; Haque, M.R. and Haque, T. M. A. 2010. Physicochemical Assessment of Surface and Groundwater Resources of Greater Comilla Region of Bangladesh. International Journal of Chemical and Environmental Engineering, 1: 2632.

Ahmed, M. F. and Rahaman, M. M. 2000. Water supply and sanitation: Rural and Low Income Urban Communities. $1^{\text {st }}$ Ed., ITN Bangladesh, Dhaka. $427 \mathrm{p}$.

Ahmed, M. F.; Shamsuddin, S. A. J.; Mahmud, S. G.; Rashid, H.; Deere, D.; Howard, G. 2005. Risk assessment of arsenic mitigation Options (RAAMO). Dhaka. 141 p.

Ayers, R. S. and Westcot, D. W. 1985. Water Quality for Agriculture. FAO Irrigation and drainage paper. 291: 8-96.

BBS. 2011. Bangladesh national drinking water quality survey of 2009. Planning Division, Ministry of planning. Government of the People's Republic of Bangladesh.

Ceron, R. M.; Ceron, J.G.; Murel, M. and Cardenas, B. 2008. Identification of ion sources in rain water of a coastal site impacted by the gas and oil industry

in the south east of Mexico. Global Nest., 10: 92100.

Cobbina, S. J.; Michael, K.; Salifu, L.; Duwiejua, A. B. 2013. Rainwater Quality Assessment In The Tamale Municipality. International Journal of Science \& Technology research, 2: 5

Dara, S. S. 2002. Environmental Chemistry and Pollution Control. S. Chand \& company Ltd. Ram nagar, New Dheli. 101 p.

Das, R.; Das, S. N. and Misra, V. N. 2005. Chemical composition of rainwater and dust fall at Bhubaneswar in the east coast of India. Atmos. Environ., 39: 5908-5916.

Deletic, A. 1998. The first flush load of urban surface runoff. Water Research, 32: 2462-2470.

DPHE and UNICEF. 1989. A Report on the Development of Pond Sand Filtration. Department of Public Health Engineering, Dhaka, Bangladesh. pp 1-17.

Gobel, P.; Dierkes, C. and Coldewey, W. G. 2007. Storm water runoff concentration matrix for urban areas. Journal of Contaminant Hydrology, 91: 2642.

Gopalkrushna, H. M. 2011. Assessment of PhysicoChemical Status of Ground Water Samples in Akot city. Research Journal of Chemical Sciences, 4: $117-124$.

Haque, M. A. K. M.; Jahan, S. M. and Azad, K. A. 2010. Shrimp culture impact on surface and ground water of Bangladesh. The $1^{\text {st }}$ international applied geological congress, department of geology, Islamic Azad University - Mashad branch, Iran.

Hari, J. and Krishna, P. E. 2005. The Texas Manual on Rainwater Harvesting. Texas Water Development Board, America.

Hussain, M. D. and ziauddin, A. T. M. 1989. Rainwater Harvesting and Storage Technique from Bangladesh. Waterlines, 10: 10-12.

Jain, C. K. 2002. A hydro-chemical study of a mountainous watershed: the Ganga, India. Water Research, 36: 1262-1274.

Karanth, K. R. 1994. Ground Water Assessment Development and Management. Tata McGraw- 
Hill Publishing Company Ltd. New Delhi, India. pp 284-250.

Kulshrestha, U. C.; Kulshrestha, M. J.; Sekar, R.; Sastry, G. S. R. and Vairamani, M. 2003. Chemical characteristics of rain water at an urban site of south-central India. Atmos. Environ, 37: 3019-3026.

Kotaiah, D. B. and Swamy, N. K. K. 1994. Environmental Engineering Laboratory Manual. Charoter publishing House, India. 104 p.

Meera, V. and Ahammed, M. M. 2006. Water quality of rooftop rainwater harvesting systems. Water Supply Research and Technology-Aqua, 55: 257268.

Melidis, P.; Akratos, C. S.; Tsihrintzis, V. A. and Trikilidou, E. 2007. Characterization of rain and roof drainage water quality in xanthi, greece. Environmental Monitoring and Assessment, 127: 15-27.

Mishra, V. N. 2003. Water-A threatened global resource. Proceedings International Conference on Water and Environment (WE-2003), Bhopal, India. pp 11-16.

Pandey, J.; Agrawal, M.; Narayan, N. and Rao, D. N. 1992. Air pollutants concentrations in Varanasi, India. Atmos. Environ., 26: 91-98.

Pandey, J. and Pandey, U. 2009. Microbial processes at land water interface and cross-domain causal relationships as influence by atmospheric deposition of pollutants in three fresh water lakes of India. Lakes and Reser. Res. Manag., 14: 71-84.

Park, K. 2005. Preventive and social medicine. M/S Banarsidas Bhanot Publishers, India. pp 520-542.
Rahman, Z. 2001. Rainwater Harvesting System. NGO Forum for Drinking water supply, Lalmatia, Dhaka, Bangladesh.

Rahman, A.; Ali, M. A. and Chowdhury, F. 2001. Peoples Report on Bangladesh Environment, Unnyan Shamanny. The University Press Limited, Dhaka. pp 111-119.

Rahman, M. M.; Hasan, M. Q. and Islam, M. S. 2000. Environmental impact assessment on water quality deterioration caused by the decfeased Ganges outflow and saline water intrusion in the southwestern Bangladesh. Environmental Geology, 40: $1-2$

Ramesh, R. and Anbu, M. 1996. Chemical method for Environmental Analysis-Water and Sediment. Rajiv Beri Macmillion Limited, India.

Rana, M. 2011. Changes in Cyclone Pattern with Climate Change Perspective in the Coastal Regions of Bangladesh. Environmental Research, Engineering and Management, 56: 20-27.

Richards, L. A. 1968. Diagnosis and Improvement of Saline and Alkaline Soils. Oxford and IBH Publishing Co. Ltd., New Delhi, India. pp 71-82.

Saha, S. K.; Saleh, A. G. M.; Jahid, M. A.; Rahanan, M. A.; Naznin, S. and Kumar, U. 2006. Monsoon rain water chemistry and its potable status: A case study from south-east coastal belt of Bangladesh. Khulna University Studies, 7(2): 1-6.

Uttran. 2003. Supaeo panir sandhane (Quest for safe water). CARE and CIDA, Satkhira, Bangladesh. pp 3-21.

WHO. 2004. Guideline for Drinking Water quality. Volume: 1 Recommendation, World Health organization, Geneva, Switzerland. 515 p. 